\title{
Risk factors of Internet Addiction and the health effect of Internet Addiction on adolescents: A systematic review of longitudinal and prospective studies
}

\author{
Lawrence T Lam ${ }^{1,2}$ \\ ${ }^{1}$ Discipline of Paediatrics and Child Health, Sydney Medical School, \\ The University of Sydney, Australia \\ ${ }^{2}$ The Hong Kong Institute of Education, Hong Kong SAR, China
}

Correspondence to:

Lawrence T Lam

The Hong Kong Institute of Education

10 Lo Ping Road,

Tai Po, N.T.

Hong Kong SAR,

CHINA

Telephone: $\quad+85229486685$

Fax: $\quad+85229487848$

E-mail: $\quad$ ltlam@ied.edu.hk 


\begin{abstract}
Internet gaming addiction was included the latest version of the DSM-V as a possible disorder recently, while debate is still on-going as to whether the condition called "Internet Addiction" (IA) could be fully recognised as an established disorder. The major contention is how well IA could fulfil the validation criteria as a psychiatric disorder as in other wellestablished behavioural addictions. In addition to various proposed validation criteria, evidence of risk and protective factors as well as development of outcomes from longitudinal and prospective studies are suggested as important. A systematic review of available longitudinal and prospective studies was conducted to gather epidemiological evidence on risk and protective factors of IA and the health effect of IA on adolescents. Nine articles were identified after an extensive search of the literature in accordance to the PRISMA guidelines. Of these, 8 provided data on risk or protective factors of IA and one focused solely on the effects of IA on mental health. Information was extracted and analysed systematically from each study and tabulated. Many exposure variables were studied and could be broadly classified into three main categories: psychopathologies of the participants, family and parenting factors, and others such as Internet usage, motivation, and academic performance. Some were found to be potential risk or protective factors of IA. It was also found that exposure to IA had a detrimental effect on the mental health of young people. These results were discussed in light of the their implications to the fulfilment of the validation criteria.
\end{abstract}

Keywords: Internet Addiction; Risk Factor; Protective Factor; Health Effect; Adolescents; Systematic Review 


\section{INTRODUCTION}

It has long been noticed that excessive use of information and communication technologies could become problematic behaviour that requires more attention.[1] In the past decade or more, different terms have been used to describe such behaviour including: "compulsive computer use"; "Internet dependency"; "pathological Internet use"; and "Internet addiction".[2-5] Some other terms have also been used to describe specific Internet use behaviours, such as: "Internet Gaming Disorder", "Internet Gaming Addiction", "Cybersex Addiction".[6-9] While the debate is still on-going as whether the condition called "Internet Addiction" (IA) could be fully recognised as an established disorder, Internet Gaming Addiction (IGA) has been included in Section III of the latest version of the Diagnostic and Statistical Manual of Mental Disorder V (DSM-V) as an emerging disorder that requires further investigation.[10] While acknowledging that there may be many different facets of the phenomenon of human behaviours related to excessive and unhealthy use of the Internet, for ease of communication the term IA will be used loosely, covering the broad range of the aforementioned behaviours.

As there are many aspects of the phenomenon, there are also different thoughts on the definition of IA and as a result, different models of assessment based on various conceptualisation of the phenomenon.[11-12] Lui and Potenza provided a historical perspective of the early development in the conceptualisation of IA from the late 90 s to the early 2000s.[11] They analysed the diagnostic criteria of IA proposed by Young which was based on the DSM-IV criteria for pathological gambling characterised by three main features: preoccupation, loss of control, and harmful effect.[5] Lui and Potenza further noted that Shapira et al. [13] had used a broader concept for the definition of IA as a behaviour that is uncontrollable; markedly distressing, and resulting in difficulties in terms of social life, occupation, and finance.[11] This view was also advocated by Ha et al. when their research team defined IA as: "the inability of individuals to control their Internet use, resulting in marked distress and/or functional impairment in daily life".[14] Such a definition was also adopted by Pies in his analysis of the conceptualisation and the diagnosis of IA. [12]

Among all the debate on IA is the major contention of how well IA could fulfil the validation criteria as a psychiatric disorder, as in other well-established behavioural addiction.[15] Robins and Guze, who first proposed a set of formal criteria for establishing the validity of psychiatric diagnoses, suggested five criteria.[16] These included: a clear clinical description of the disorder; evidence from laboratory studies; exclusion of other disorders; evidence from follow-up studies; and family studies.[16] Pies echoed this view by advocating his set of criteria that at least one of the three needed to be satisfied, namely a genetic linkage on a specific locus to the condition; a well-known aetiology or pathology; and the course, prognosis, stability, and response to treatment should be relatively consistent across different populations.[12] A similar set of criteria was also put forwarded by Gentile et al in which, first and foremost, information on the aetiological risk and protective factors of IA as well as the comorbidities of IA were important for the determination of its validity as a psychiatric disorder.[17] In attempting to gather evidence for the satisfaction of the aforementioned criteria, various studies were reported. For example, to examine the issue of comorbidities of IA, Ko et al. conducted a systematic review of the literature on the association between IA and psychiatric disorders.[18•] A number of disorders were identified as comorbidities of IA. These included: substance use, attention-deficit hyperactivity disorder, depression, and social anxiety disorder.[18•] However, in terms of aetiological risk and protective factors, as well as the course and prognosis of IA, information 
could only be provided by well-designed epidemiological studies of a longitudinal or prospective nature, as highlighted as one of the criteria by Robins and Guze.[16]

The aim of this study is to examine the available information through a systematic review of longitudinal or prospective studies on possible risk and protective factors of IA, as well as the effect of IA on the health of adolescents. The reasons for choosing adolescents as the target population of this study are twofold: 1) it has been demonstrated that IA is more prevalent in adolescents than in other age groups; 2) there are far more studies available in this age group than in others.

\section{METHODS}

\section{Search strategies}

The PRISMA guidelines for systematic reviews and meta-analysis were employed for the conduct of the literature search following a systematic and structured approach.[19] Major medical, health, and psychological literature databases including PubMed, MEDLINE with Full Text, Cochrane Database for Systematic Review, and PsychINFO were used and the search included all publication years (till June 2014). The keywords used for the systematic search were: ("excessive Internet use" or "problematic Internet use" or "pathological Internet use" or "Internet addiction" or "excessive computer use" or "Internet gaming" or "computer gaming" or "Internet gaming addiction" of " Internet gaming disorder") AND ("longitudinal study" or " prospective study" or "cohort study" or "follow-up study"). Included in the search were articles published as reviews for the purpose of identifying relevant studies. However, these review articles were not included in this systematic review. Limitations were imposed on the search for publications in the English language only and the study subjects were adolescents loosely defined as young people aged between 13 to 18 years. Upon completion of the search on the electronic database, titles and abstracts of the identified articles were assessed for their suitability to the included in the review. Additional searches were also conducted on other "grey" literature database such as Google scholar. After assessing the titles and abstracts, full text of the articles deemed suitable were retrieved for further examination of the contents of the studies to determine their final inclusion in the review. Furthermore, the reference lists of the selected articles were also examined for additional suitable publications that might have been overlooked in the previous search.

\section{Selection Criteria}

The following selection criteria were applied for suitable articles: 1) epidemiological studies with appropriate study design that included a cohort of participants recruited with the exposure variable assessed at baseline and then followed for a period of time for outcome measures; 2) examined the relationship between some potential risk factors (exposure) of IA (outcome), or the effect of IA (exposure) on the health (outcome) of the participants; 3 ) the assessment of IA, as an exposure or an outcome variable, was conducted using a validated and standardised instrument based on a sound theoretical framework; 4) the assessment of risk factors and health was conducted using a validated and standardised instrument; 5) provided information on the risk estimate of the relationship. Conference proceedings, abstracts, and non-peer-reviewed journal articles were excluded from this review.

\section{Information extraction and analysis}

Information was extracted from the selected articles and tabulated for further analysis. Of interest was information on the relationship between potential risk or protective factors and IA. These might include personal, familial, parental, Internet usage, psychopathologies, and 
personality factors. Additionally, the effect of IA on the health of young people was also relevant to the review. Information extracted from the selected studies included the location of the study, study design, study sample, assessment of the exposure and outcome variables, analytical approach, estimated effects, and other information or remarks relevant to the study. This information was then summarised and analysed by the risk and protective factors of IA and the effects of IA on health separately.

\section{RESULTS}

Following the aforementioned procedures, an extensive search was conducted resulting in 23 articles reporting on a longitudinal or prospective study in the English language on Internet use among adolescents.[14, 20-42] After examining the abstract of these reports, 14 were possible candidates for inclusion in the review. A closer examination of the full text of these articles revealed that only 9 satisfied the selection criteria and contained sufficient information. Of these 9 articles, 8 provided data on risk or protective factors of IA and one focused solely on the effects of IA on mental health. [24-26,28,30,35,38,39•,41] Among the articles reporting on risk or protective factors of IA, a cohort of Taiwanese adolescents had been used three times resulting in three articles on different risk factors.[25,35,41]These were included as three separate reports in the analysis. The main reason for the exclusion of other articles was that they focused on other Internet use but not IA. As a result, 8 reports on the risk or protective factors and IA and 1 on the effects of IA on mental health were included. Detailed information was extracted from these articles and summarised in Table 1 and 2.

\section{The risk or protective factors of Internet Addition}

In terms of the study design, nearly all but one utilised self-reported questionnaire surveys to collect baseline data and the cohort was resurveyed for the outcome measures with follow-up periods ranging from 6 to 36 months. The only exception was the report by Cho et al. in which parents had been recruited as informants to provide data on the psychopathology of their children at childhood with a follow-up period of 7 years.[39•] The majority of the reported studies utilised a large sample size of more than 1000 participants recruited from primary to junior high schools except three with a smaller sample size of about 500.[24,26,39•] For assessment of IA, the reported studies mainly used three validated instruments: The Compulsive Internet Use Scale designed by Van Rooij et al., Young's Internet Addiction Test, and Chen's Internet Addiction Scale. In terms of the risk factors, many exposure variables were studied and could be broadly classified into three main categories: psychopathologies of the participants, family and parental factors, and others such as Internet usage, motivation, and academic performance. In all these studies, appropriate statistical analytical approaches were employed including multivariate logistic regression modelling, Cox proportional hazard regression modelling, and the Structural Equation modelling with adjustments to some potential confounding factors in all studies but one. However, it was also noted that nearly all of these studies had utilised schools as the sampling unit, but none considered the effect of school in their analyses. The results of these studies suggested a number of potential risk factors of IA. For psychopathologies, Ko et al. found that Taiwanese young people who had been assessed with Attention Deficit and Hyperactivity Disorder, and hostility at baseline were at a higher risk of IA at follow-up with a Hazard Ratio of 1.72 (95\%C.I.=1.21-2.43) for the former and 1.67 (95\%C.I.=1.17-2.68) for the latter.[25] Cho et al. also found that children who had been assessed with Withdrawal, Anxious/ Depressed, and Thought problems at childhood were also at a higher risk of IA 7 years later in adolescence with Odds Ratios of 1.16, 1.07, and 1.19 respectively.[39] In terms of familial and parental factors, Ko et al. reported that conflict between parent and child due to the Internet at baseline was significantly related to IA 12 months later $(\mathrm{OR}=2.31$, 
95\%C.I.=1.28-4.18).[25] At the same time, not living with mother was also identified as a potential risk factor of IA in the same cohort of adolescents $(\mathrm{OR}=1.66$, 95\%C.I.=1.03-2.69). Other potential risk factors were also identified including usage of the Internet with a strong association between online gaming and IA $(\beta=0.15, p<0.001),[24]$ and young people who had adopted the Behaviour Approach System as a motivation style were found to be more at risk of IA $(\mathrm{OR}=1.05$ 95\%C.I.=1.02-1.09).[35] On the contrary, some protective factors were also reported from these studies. In the study by Van den Eijnden et al., it was found that quality communication between parents and children on Internet use at baseline significantly reduced the risk of compulsive Internet use at follow-up among young people in the Netherlands $(\beta=$ $0.10, \mathrm{p}<0.05)$.[26] A recent study in Hong Kong also revealed that higher scores of positive youth development significantly related to a lower risk of IA $(\mathrm{OR}=0.67)$.[38]

\section{The effect of IA on mental health}

The systematic search of longitudinal or prospective studies on the effects of IA on health of young people yielded only one study that satisfied the selection criteria of this review. The study was a longitudinal study on healthy Chinese young people who were depression free at baseline, with results indicating that those who had been classified as having moderate to severe risk of IA were about 2.5 times more likely to develop depressive symptoms and scored high enough on the Zung Depression Scale to be clinically significant in comparison to normal users at follow-up 9 months later.[30]

\section{DISCUSSION and CONCLUSIONS}

The structured PRISMA guidelines for systematic review were followed in this review study. The guidelines were established to ensure that proper and systematic procedures are implemented in the process of a systematic review. Nine studies fulfilled the selection criteria and contained potentially useful information on the risk or protective factors of IA as well as the effect of IA on the mental health of young people. The results of these studies provided some evidence on possible linkages between those risk or protective factors and IA, as well as the exposure to IA on the mental health of adolescents.

These results have shed some light on the aetiology of the problem as well as the effect of the problem on the health, particularly the mental health, of adolescents. It is apparent that the aetiology of IA is rather complex and there are a range of possible risk factors that may influence the onset and the development of the problem. As indicated from the results, these factors relate to different facets of adolescent life ranging from childhood development and psychopathologies, to communication with parents. These results have also contributed to the understanding and conceptualisation of the underlying aetiological mechanism of IA. As there are many proposed definitions, different conceptual frameworks have also been proposed as the theoretical basis for the understanding of IA, particularly among adolescents.[43,44] Among these theoretical models, stress or anxiety reduction has been proposed as a possible explanatory theory for IA.[45] According to this theory, the motivation for the behavioural maintenance of IA of "over-users" is that the Internet is used as a means for stress or tension reduction.[45] Another theory which has also been receiving much attention, especially for IA among adolescents, is the Problem Behaviour Theory.[4648] The Problem Behaviour Theory advocates that there are three main systems, namely the personality, environment, and the behavioural systems, in the conceptual structure of any problematic behaviours in young people.[49,50] The propensity of any involvement in problematic behaviours is determined by the balance among risk and protective factors in the three systems.[50] Moreover, the behaviour system is also influenced by interactions between the personality and environment systems. According to Jessor et al., familial and parental 
factors, such as parental behaviours and attitudes, are the main focus of the environment system, and risk factors in the personality system include lack of achievement, alienation, and self-dissatisfaction.[50] The results of this review render some support to the Problem Behaviour Theory of IA development among adolescents.

The results obtained from this review also have direct implications on the validation criteria of IA as a psychiatric problem. While Robins and Guze called for the evidence of follow-up studies as one the criteria for establishing the validity of a psychiatric diagnoses, Gentile et al also advocated the identification of risk and protective factors to be considered as an essential requirement for the establishment of a valid psychiatric diagnosis of IA.[16,17] The results seem to suggest successful identification of some risk and protective factors from the longitudinal and prospective studies. However, on closer examination one would find that the evidence derived from these results may not be as solid as one would wish. It is mainly due to the problem that, despite the fact that different instruments based on slightly different design conceptualisations were used for the assessment of IA, these studies were focused on different exposure variables. There is little overlap of exposure variables, except depression, across all these studies. In terms of pooling information together from different individual studies for the establishment of potential causal relationships between the exposure and the outcome variables in a specific area, the included studies in this review could not fulfil the task. There is a need for more studies of the same design focusing on the same area in order to offer evidence of sufficient quality for the establishment of the relationship. In this connection, it is suggested that these studies be repeated in other populations of young people at different geographical locations.

In conclusion, some potential risk and protective factors have been suggested from the included studies. In terms of the effect of IA, there is indicative evidence of the effect of IA on the mental health, particularly depression, of adolescents. The results of the review found that, due to the aforementioned limitations, more similar studies should be conducted to verify the findings of the reported studies in order to provide sufficient evidence for the fulfilment of the validation criteria of a psychiatric disorder. 


\section{REFERENCES}

Papers of particular interest, of importance to this review, are published within the past 3 years, have been highlighted with

1. Shotton MA. The costs and benefits of "computer addiction". Behav Inf Technol. 1991; 10:219-30.

2. Potenza MN, Hollander E. Pathological gambling and impulse control disorders. In Davis KL, et al., eds. Neuropsychopharmacology: the Fifth generation of Progress. $5^{\text {th }}$ ed. Baltimore, Md: Lippincott Williams \& Wilkins; 2002:1736-37.

3. Scherer K. College life on-line: healthy and unhealthy Internet use. JCSD. 1997; 38:65565.

4. Morahan-Martin J, Schumacher P. Incidence and correlates of pathological Internet use among college students. Comp Human Behav. 2000; 16:13-39.

5. Young KS. Internet addiction: the emergence of a new clinical disorder. Cyberpsychol Behav. 1998; 11:237-44.

6. Petry NM, O'Brien CP. Internet gaming disorder and the DSM-5.Addiction. 2013; 108:1186-7.

7. Petry NM, Rehbein F, Gentile DA, Lemmens JS, Rumpf HJ, Mößle T, Bischof G, Tao R, Fung DS, Borges G, Auriacombe M, González Ibáñez A, Tam P, O'Brien CP. An international consensus for assessing internet gaming disorder using the new DSM-5 approach. Addiction. 2014; Epub ahead of print.

8. Sattar P, Ramaswamy S. Internet gaming addiction. Can J Psychiatry. 2004; 49:869-70.

9. Rosenberg KP, Carnes P, O'Connor S. Evaluation and treatment of sex addiction. J Sex Marital Ther. 2014; 40:77-91.

10. Diagnostic and Statistical Manual of Mental Disorders. $5^{\text {th }}$ ed. Washington, DC: American Psychiatric Association; 2013.

11. Liu T, Potenza MN. Problematic Internet Use: clinical implications. CNS Spectr. 2007; 12: 453-466.

12. Pies R. Should DSM-V designate "Internet Addiction" a mental disorder? Psychiat 2009; 6: 31-37.

13. Shapira NA, Goldsmith TD, Keck Jr PE, Khosla UM, McElory SL. Psychiatric features of individuals with problematic Internet use. J Affect Disord. 2000; 54:267-272.

14. Ha JH, Yoo HJ, Cho IH, Chin B, Shin D, Kim JH. Psychiatric comorbidity assessed in Korean children and adolescents who screen positive for internet addiction. J Clin Psychiatry 2006; 67:821-826.

15. George S, Lenihan F. Is Internet addiction a valid psychiatric disorder? Available on: http://priory.com/psychiatry/Internet_Addiction.htm. (last accessed 06/05/2014)

16. Robins E, Guze SB. Establishment of psychiatric validity in psychiatric illness: its application to schizophrenia. American Journal of Psychiatry 1970; 126:983-7.

17. Gentile DA, Choo H, Liau A, Sim T, Li D, Fung D, Khoo A. Pathological video game use among youths: A two-year longitudinal study. Pediatrics 2011; 127:e319.

18. - Ko CH, Yen JY, Yen CF, Chen CS, Chen CC. The association between Internet addiction and psychiatric disorder: a review of literature. European Psychiatry 2012; 27: 1-8. The systematic review study provided a comprehensive review of the literature in the 
area of psychiatric co-morbidities of Internet Addiction from 2000 onward. Ko et al., provided a good summary of the reviewed studies broken down by types of psychiatric disorder while exploring the association of these disorders and Internet Addiction. It is a rather easy reading, but informative.

19. Moher D, Libertai A, Tetzlaff $\mathrm{j}$, et al. Preferred reporting items for systematic reviews and meta-analysis- the PRISMA statement. BMJ. 2009; 339:332-6

20. Tsai CC, Lin SS. Internet addiction of adolescents in Taiwan: an interview study. Cyberpsychol Behav. 2003; 6:649-52.

21. Meerkerk GJ, Van Den Eijnden RJ, Garretsen HF. Predicting compulsive Internet use: it's all about sex! Cyberpsychol Behav. 2006; 9:95-103.

22. Chuang YC. Massively multiplayer online role-playing game-induced seizures: a neglected health problem in Internet addiction. Cyberpsychol Behav. 2006; 9:451-6.

23. Ko CH, Yen JY, Yen CF, Lin HC, Yang MJ. Factors predictive for incidence and remission of internet addiction in young adolescents: a prospective study. Cyberpsychol Behav. 2007; 10:545-51.

24. van den Eijnden RJ, Meerkerk GJ, Vermulst AA, Spijkerman R, Engels RC. Online communication, compulsive Internet use, and psychosocial well-being among adolescents: a longitudinal study. Dev Psychol. 2008; 44:655-65.

25. Ko CH, Yen JY, Chen CS, Yeh YC, Yen CF. Predictive values of psychiatric symptoms for internet addiction in adolescents: a 2-year prospective study. Arch Pediatr Adolesc Med. 2009; 163:937-43.

26. van den Eijnden RJ, Spijkerman R, Vermulst AA, van Rooij TJ, Engels RC. Compulsive internet use among adolescents: bidirectional parent-child relationships. J Abnorm Child Psychol. 2010; 38:77-89.

27. Fu KW, Chan WS, Wong PW, Yip PS. Internet addiction: prevalence, discriminant validity and correlates among adolescents in Hong Kong. Br J Psychiatry. 2010; 196:486-92.

28. van Rooij AJ, Schoenmakers TM, van de Eijnden RJ, van de Mheen D. Compulsive Internet use: the role of online gaming and other internet applications. J Adolesc Health. 2010; 47:51-7.

29. de Leeuw JR, de Bruijn M, de Weert-van Oene GH, Schrijvers AJ. Internet and game behaviour at a secondary school and a newly developed health promotion programme: a prospective study. BMC Public Health. 2010; 10:544.

30. Lam LT, Peng ZW. Effect of pathological use of the internet on adolescent mental health: a prospective study. Arch Pediatr Adolesc Med. 2010; 164:901-6.

31. Dowling NA, Brown M. Commonalities in the psychological factors associated with problem gambling and Internet dependence. Cyberpsychol Behav Soc Netw. 2010; 13:437-41.

32. Van Rooij AJ, Schoenmakers TM, Vermulst AA, Van den Eijnden RJ, Van de Mheen D. Online video game addiction: identification of addicted adolescent gamers. Addiction. 2011; 106:205-12.

33. Bener A, Al-Mahdi HS, Ali AI, Al-Nufal M, Vachhani PJ, Tewfik I. Obesity and low vision as a result of excessive Internet use and television viewing. Int J Food Sci Nutr. $2011 ; 62: 60-2$. 
34. Han DH, Renshaw PF. Bupropion in the treatment of problematic online game play in patients with major depressive disorder. J Psychopharmacol. 2012; 26:689-96.

35. Yen JY, Cheng-Fang Y, Chen CS, Chang YH, Yeh YC, Ko CH. The bidirectional interactions between addiction, behaviour approach and behaviour inhibition systems among adolescents in a prospective study. Psychiatry Res. 2012; 200:588-92.

36. Sun P, Johnson CA, Palmer P, Arpawong TE, Unger JB, Xie B, Rohrbach LA, SpruijtMetz D, Sussman S. Concurrent and predictive relationships between compulsive internet use and substance use: findings from vocational high school students in China and the USA. Int J Environ Res Public Health. 2012; 9:660-73.

37. Park S, Hong KE, Park EJ, Ha KS, Yoo HJ. The association between problematic internet use and depression, suicidal ideation and bipolar disorder symptoms in Korean adolescents. Aust N Z J Psychiatry. 2013; 47:153-9.

38. Yu L, Shek DT. Internet addiction in Hong Kong adolescents: a three-year longitudinal study. J Pediatr Adolesc Gynecol. 2013; 26(3 Suppl):S10-7.

39. - Cho SM, Sung MJ, Shin KM, Lim KY, Shin YM. Does psychopathology in childhood predict internet addiction in male adolescents? Child Psychiatry Hum Dev. 2013; 44:54955. Cho et al study on the aetiological relationship between childhood psychopathology and Internet Addiction in adolescents. This is the only longitudinal study that had a follow-up period longer than 3 years and covered the entire population of children in a city. In fact the full follow-up period of the cohort was 7 years since the baseline data collection. Moreover, this is the only longitudinal study that employed parents as informants instead of self-report by the participants so far. The short-coming of the study was that it had a rather high drop-out rate.

40. Mittal VA, Dean DJ, Pelletier A. Internet addiction, reality substitution and longitudinal changes in psychotic-like experiences in young adults. Early Interv Psychiatry. 2013; 7:261-9.

41. Ko CH, Wang PW, Liu TL, Yen CF, Chen CS, Yen JY. The bidirectional associations between the family factors and internet addiction among adolescents in a prospective investigation. Psychiatry Clin Neurosci. 2014; Epub ahead of print.

42. Yang SJ, Stewart R, Lee JY, Kim JM, Kim SW, Shin IS, Yoon JS. Prevalence and correlates of problematic internet experiences and computer-using time: a two-year longitudinal study in Korean school children. Psychiatry Investig. 2014;11:24-31.

43. Liu CY, Kuo FY. A study of Internet Addiction through the lens of the interpersonal theory. Cyberpsychol Behav 2007; 10:799-804.

44. Snodgrass JG, Dengah HJ 2nd, Lacy MG, Fagan J. A formal anthropological view of motivation models of problematic MMO play: achievement, social, and immersion factors in the context of culture. Transcult Psychiatry 2013; 50(2):235-62.

45. Kim H, Davis K. Towards a comprehensive theory of problematic Internet use: Evaluating the role of self-esteem, anxiety, flow, and the self-rated importance of Internet activities. Compter Hum Behav 2009; 25:490-500.

46. De Leo JA, Wulfert E. Problematic Internet use and other risky behaviors in college students: an application of problem-behavior theory. Psychol Addict Behav 2013; 27:133-41. 
47. Ko CH, Yen JY, Yen CF, Chen CS, Weng CC, Chen CC. The association between Internet addiction and problematic alcohol use in adolescents: the problem behavior model. Cyberpsychol Behav 2008; 11:571-6.

48. Yen JY, Ko CH, Yen CF, Chen SH, Chung WL, Chen CC. Psychiatric symptoms in adolescents with Internet addiction: Comparison with substance use. Psychiatry Clin Neurosci 2008; 62:9-16.

49. Jessor R. Problem-behavior theory, psychosocial development, and adolescent problem drinking.Br J Addict 1987; 82:331-42.

50. Jessor R, Costa FM, Krueger PM, Turbin MS. A developmental study of heavy episodic drinking among college students: the role of psychosocial and behavioral protective and risk factors. J Stud Alcohol 2006; 67:86-94. 
Table 1. Information extracted from individual longitudinal or prospective cohort studies on risk factors of Internet Addiction in adolescents.

\begin{tabular}{|c|c|c|c|c|c|c|c|}
\hline $\begin{array}{c}\text { Reference } \\
\text { (Author, year, } \\
\text { place) }\end{array}$ & $\begin{array}{c}\text { Study design \& } \\
\text { methods }\end{array}$ & Participants & $\begin{array}{l}\text { Exposure \& } \\
\text { Outcome } \\
\text { Variable }\end{array}$ & $\begin{array}{l}\text { Method of } \\
\text { analysis }\end{array}$ & $\begin{array}{l}\text { Variables } \\
\text { Adjusted }\end{array}$ & Results & Comments \\
\hline $\begin{array}{l}\text { Van den Eijnden } \\
\text { et al. (2008), } \\
\text { Netherlands [24] }\end{array}$ & $\begin{array}{l}\text { Design: } \\
\text { Self-reported } \\
\text { questionnaire } \\
\text { surveys at two } \\
\text { times. } \\
\text { Follow-up } \\
\text { duration: } \\
6 \text { months in } \\
\text { between two } \\
\text { surveys }\end{array}$ & $\begin{array}{l}\text { Eighth grade } \\
\text { students from } 4 \\
\text { schools recruited } \\
\text { form the } \\
\text { southern part of } \\
\text { the Netherlands } \\
(\mathrm{N}=660)\end{array}$ & $\begin{array}{l}\text { Exposure } \\
\text { variable: } \\
\text { - Internet usage } \\
\text { assessed by } \\
\text { the frequency } \\
\text { of different } \\
\text { Internet } \\
\text { usages; } \\
\text { - Depressive } \\
\text { symptoms } \\
\text { assessed by } \\
\text { the Depressive } \\
\text { Mood List; } \\
\text { - Loneliness } \\
\text { measured by } \\
\text { the Loneliness } \\
\text { Scale. } \\
\text { Outcome } \\
\text { variable: } \\
\text { Compulsive } \\
\text { Internet use } \\
\text { assessed by the } \\
\text { Compulsive } \\
\text { Internet Use } \\
\text { Scale }\end{array}$ & $\begin{array}{l}\text { Data were } \\
\text { analysed using } \\
\text { structural } \\
\text { equation } \\
\text { modelling } \\
\text { (SEM). Of } \\
\text { interest to this } \\
\text { review was the } \\
\text { cross-lagged } \\
\text { analysis with } \\
\text { panel data. More } \\
\text { specifically was } \\
\text { the effect of the } \\
\text { exposure } \\
\text { variable on the } \\
\text { outcome } \\
\text { variable. }\end{array}$ & $\begin{array}{l}\text { Instant } \\
\text { messaging, } \\
\text { depression, } \\
\text { loneliness, and } \\
\text { compulsive } \\
\text { Internet use from } \\
\text { time } 1 \text { were } \\
\text { included in the } \\
\text { model as } \\
\text { predictor of the } \\
\text { same four } \\
\text { variables at time } \\
\text { 2. Separate } \\
\text { analyses were } \\
\text { conducted for } \\
\text { males and } \\
\text { females for } \\
\text { testing the } \\
\text { moderating } \\
\text { effect of gender. }\end{array}$ & $\begin{array}{l}\text { Instant } \\
\text { messaging at } \\
\text { time } 1 \text { was } \\
\text { positively and } \\
\text { significantly } \\
\text { associated with } \\
\text { compulsive } \\
\text { Internet use for } \\
\text { girls at time } 2 \\
(\beta=0.14, p<0.05) \text {, } \\
\text { but not for males. }\end{array}$ & $\begin{array}{l}\text { - The same } \\
\text { cohort was } \\
\text { followed with } \\
\text { low attrition } \\
\text { rate. } \\
\text { - No adjustment } \\
\text { made for } \\
\text { school effect. }\end{array}$ \\
\hline Ko et al. (2009), & Design: & Seventh grade & Exposure & Data were & Age and gender & ADHD was & - The \\
\hline
\end{tabular}




\begin{tabular}{|c|c|c|c|c|c|c|c|}
\hline Taiwan [25] & $\begin{array}{l}\text { Self-reported } \\
\text { questionnaire } \\
\text { surveys at } \\
\text { baseline and } \\
\text { other three time } \\
\text { points } \\
\text { Follow-up } \\
\text { duration: } \\
6,12 \text {, and } 24 \\
\text { months. }\end{array}$ & $\begin{array}{l}\text { students } \\
\text { randomly } \\
\text { selected from } 10 \\
\text { junior high } \\
\text { schools with } 4 \\
\text { urban, } 4 \\
\text { suburban, and } 2 \\
\text { rural schools in } \\
\text { southern Taiwan } \\
\text { in } 2005 \text {. Only } \\
\text { those who were } \\
\text { assessed without } \\
\text { Internet } \\
\text { Addiction at } \\
\text { baseline were } \\
\text { included in the } \\
\text { analysis } \\
\text { (N=1848) }\end{array}$ & $\begin{array}{l}\text { variable: } \\
\text { - Attention } \\
\text { Deficit/hyperact } \\
\text { ivity disorders } \\
\text { assessed by the } \\
\text { ADHD Self- } \\
\text { rated Scale; } \\
\text { - Depression } \\
\text { assessed by the } \\
\text { CED-D; } \\
\text { - Social phobia } \\
\text { measured by } \\
\text { Fear of Negative } \\
\text { Evaluation } \\
\text { Scale; } \\
\text { - Hostility } \\
\text { assessed by } \\
\text { Buss-Durkee } \\
\text { Hostility } \\
\text { Inventory- } \\
\text { Chinese Short } \\
\text { Form. } \\
\text { Outcome } \\
\text { variable: } \\
\text { Internet } \\
\text { Addiction } \\
\text { measured by the } \\
\text { Chen Internet } \\
\text { Addiction Scale. }\end{array}$ & $\begin{array}{l}\text { analysed using } \\
\text { Cox proportional } \\
\text { hazard regression } \\
\text { model. }\end{array}$ & & $\begin{array}{l}\text { significantly } \\
\text { associated with } \\
\text { Internet } \\
\text { Addiction } \\
(\mathrm{HR}=1.72 \text {, } \\
\text { 95\%C.I.=1.21- } \\
\text { 2.43). Hostility } \\
\text { was also } \\
\text { associated with } \\
\text { Internet } \\
\text { Addiction } \\
\text { (HR=1.67, } \\
\text { 95\%C.I.=1.17- } \\
2.38)\end{array}$ & $\begin{array}{l}\text { relationship } \\
\text { between } \\
\text { exposure and } \\
\text { outcome } \\
\text { variables was } \\
\text { examined in a } \\
\text { cohort withou } \\
\text { Internet } \\
\text { Addiction at } \\
\text { baseline. } \\
\text { - No adjustmen } \\
\text { made for } \\
\text { school effect. }\end{array}$ \\
\hline $\begin{array}{l}\text { Van den Eijnden } \\
\text { et al. (2010), } \\
\text { Netherlands [26] }\end{array}$ & $\begin{array}{l}\text { Design: } \\
\text { Self-reported } \\
\text { online } \\
\text { questionnaire } \\
\text { surveys at }\end{array}$ & $\begin{array}{l}\text { Adolescents aged } \\
10 \text { to } 15 \text { who } \\
\text { used the MSN } \\
\text { instant } \\
\text { messenger were }\end{array}$ & $\begin{array}{l}\text { Exposure } \\
\text { variable: } \\
\text { Internet specific } \\
\text { parenting } \\
\text { practices }\end{array}$ & $\begin{array}{l}\text { Data were } \\
\text { analysed using } \\
\text { structural } \\
\text { equation } \\
\text { modelling }\end{array}$ & $\begin{array}{l}\text { Internet } \\
\text { parenting } \\
\text { practices at T2 } \\
\text { and Compulsive } \\
\text { Internet use at }\end{array}$ & $\begin{array}{l}\text { Quality } \\
\text { communication } \\
\text { about Instant use } \\
\text { at time } 1 \\
\text { significantly }\end{array}$ & $\begin{array}{l}\text { - High attrition } \\
\text { rate at follow- } \\
\text { up with only } \\
31 \% \\
\text { responded }\end{array}$ \\
\hline
\end{tabular}




\begin{tabular}{|c|c|c|c|c|c|c|c|}
\hline & $\begin{array}{l}\text { baseline in } 2006 \\
\text { and a follow-up } \\
\text { Follow-up } \\
\text { duration: } \\
6 \text { months. }\end{array}$ & $\begin{array}{l}\text { recruited through } \\
\text { an advertising } \\
\text { banner with } 1647 \\
\text { respondents at } \\
\text { baseline and } 510 \\
\text { responded at } \\
\text { follow-up. } \\
\text { Response rate } \\
\text { was } 31 \% \text {. }\end{array}$ & $\begin{array}{l}\text { assessed by a } \\
\text { newly developed } \\
\text { Internet } \\
\text { parenting } \\
\text { practice scale } \\
\text { designed and } \\
\text { validate by the } \\
\text { authors. } \\
\text { Outcome } \\
\text { variable: } \\
\text { Compulsive } \\
\text { Internet use } \\
\text { assessed by the } \\
\text { Compulsive } \\
\text { Internet Use } \\
\text { scale also } \\
\text { designed and } \\
\text { validated by the } \\
\text { authors }\end{array}$ & $\begin{array}{l}\text { (SEM). Of } \\
\text { interest to this } \\
\text { review was the } \\
\text { cross-lagged } \\
\text { analysis with } \\
\text { panel data. More } \\
\text { specifically was } \\
\text { the effect of the } \\
\text { exposure } \\
\text { variable on the } \\
\text { outcome } \\
\text { variable. }\end{array}$ & $\begin{array}{l}\text { T1 were } \\
\text { included in the } \\
\text { analysis. Age, } \\
\text { gender and } \\
\text { school were also } \\
\text { included in the } \\
\text { model to control } \\
\text { for their effects. }\end{array}$ & $\begin{array}{l}\text { decreased the } \\
\text { risk of } \\
\text { compulsive } \\
\text { Internet use at } \\
\text { time } 2(\beta=-0.10 \text {, } \\
\text { p }<0.05) \text {, }\end{array}$ & $\begin{array}{l}\text { both surveys. } \\
\text { Drop-outs } \\
\text { analysis } \\
\text { indicated that } \\
\text { drop-outs were } \\
\text { more likely to } \\
\text { follow a lower } \\
\text { level of } \\
\text { education than } \\
\text { the } \\
\text { respondents of } \\
\text { both surveys. } \\
\text { - Potential } \\
\text { sampling bias } \\
\text { that might } \\
\text { cause problem } \\
\text { in generalising } \\
\text { the results. } \\
\text { - Adjustment } \\
\text { made for } \\
\text { school effect. }\end{array}$ \\
\hline
\end{tabular}




\begin{tabular}{|c|c|c|c|c|c|c|c|}
\hline & & & $\begin{array}{l}\text { Compulsive } \\
\text { Internet Use } \\
\text { scale }\end{array}$ & & & $\mathrm{p}<0.001)$ & $\begin{array}{l}\text { factors of } \\
\text { Internet } \\
\text { addictive } \\
\text { behaviours. } \\
\text { - No adjustment } \\
\text { made for } \\
\text { school effect. }\end{array}$ \\
\hline $\begin{array}{l}\text { Yen et al. (2012), } \\
\text { Taiwan [35] }\end{array}$ & $\begin{array}{l}\text { Design: } \\
\text { Self-reported } \\
\text { questionnaire } \\
\text { surveys in two } \\
\text { consecutive } \\
\text { years. } \\
\text { Follow-up } \\
\text { duration: } \\
12 \text { months } \\
\text { between two } \\
\text { surveys }\end{array}$ & $\begin{array}{l}\text { Seventh grade } \\
\text { students } \\
\text { randomly } \\
\text { selected from } 10 \\
\text { junior high } \\
\text { schools with } 4 \\
\text { urban, } 4 \\
\text { suburban, and } 2 \\
\text { rural schools in } \\
\text { southern Taiwan } \\
\text { in } 2005 . \text { Only } \\
\text { those who were } \\
\text { assessed without } \\
\text { Internet } \\
\text { Addiction at } \\
\text { baseline were } \\
\text { included in the } \\
\text { analysis } \\
\text { (N=1578) }\end{array}$ & $\begin{array}{l}\text { Exposure } \\
\text { variable: } \\
\text { Motivation } \\
\text { factors, } \\
\text { Behaviour } \\
\text { Inhibition } \\
\text { System (BIS) } \\
\text { and Behaviour } \\
\text { Approach } \\
\text { System (BAS) } \\
\text { according to the } \\
\text { Gary's } \\
\text { reinforcement } \\
\text { sensitivity } \\
\text { theory. BIS/ } \\
\text { BAS were } \\
\text { assessed using } \\
\text { the BIS/BAS } \\
\text { scales. } \\
\text { Outcome } \\
\text { variable: } \\
\text { Internet } \\
\text { Addiction } \\
\text { measured by the } \\
\text { Chen Internet } \\
\text { Addiction Scale. }\end{array}$ & $\begin{array}{l}\text { Data were } \\
\text { analysed using } \\
\text { logistic } \\
\text { regression } \\
\text { modelling. Of } \\
\text { interest of this } \\
\text { review was the } \\
\text { predictive value } \\
\text { of the BIS and } \\
\text { BAS on Internet } \\
\text { Addiction }\end{array}$ & Age and gender & $\begin{array}{l}\text { There was a } \\
\text { significant } \\
\text { relationship } \\
\text { between BAS at } \\
\text { baseline and } \\
\text { Internet } \\
\text { Addiction } 12 \\
\text { months later } \\
(\mathrm{OR}=1.05 \\
95 \% \text { C.I. }=1.02- \\
1.09)\end{array}$ & $\begin{array}{l}\text { - The same } \\
\text { study cohort as } \\
\text { that report } \\
\text { previously by } \\
\text { Ko et al. } 2009 \\
\text { [Ref]. } \\
\text { - No adjustment } \\
\text { made for } \\
\text { school effect. }\end{array}$ \\
\hline Yu \& Shek & Design: & Students were & Exposure & Data were & Age, gender, & Higher scores of & - No adjustment \\
\hline
\end{tabular}




\begin{tabular}{|c|c|c|c|c|c|c|c|}
\hline $\begin{array}{l}\text { (2013), Hong } \\
\text { Kong [38] }\end{array}$ & $\begin{array}{l}\text { Self-reported } \\
\text { questionnaire } \\
\text { surveys at } 3 \\
\text { waves of data } \\
\text { collection. This } \\
\text { study only } \\
\text { utilised data } \\
\text { collected in wave } \\
1 \text { and } 3 \text {. } \\
\text { Follow-up } \\
\text { duration: } \\
\text { Waves 1had been } \\
\text { conducted in } \\
2008 \text { and waves } \\
3 \text { was in } \\
2011 / 12 \text {. }\end{array}$ & $\begin{array}{l}\text { recruited from } 28 \\
\text { secondary } \\
\text { schools selected } \\
\text { from all } \\
\text { secondary } \\
\text { schools in Hong } \\
\text { Kong. Included } \\
\text { in the study were } \\
\text { those who could } \\
\text { be matched } \\
\text { across all three } \\
\text { waves of survey. } \\
\text { (N=2667) }\end{array}$ & $\begin{array}{l}\text { variable: } \\
\text { - Family factors } \\
\text { assessed by } \\
\text { the Chinese } \\
\text { Family } \\
\text { Assessment } \\
\text { Instrument } \\
\text { - Positive Youth } \\
\text { Development } \\
\text { measured by } \\
\text { the Chinese } \\
\text { Positive } \\
\text { Development } \\
\text { Scale } \\
\text { - Academic } \\
\text { Performance } \\
\text { assessed by } \\
\text { the Academic } \\
\text { and School } \\
\text { Competence } \\
\text { Scale. } \\
\text { Outcome } \\
\text { variable: } \\
\text { Internet } \\
\text { Addiction } \\
\text { measured by the } \\
\text { Young's } 10 \\
\text { Internet } \\
\text { Addiction Test. }\end{array}$ & $\begin{array}{l}\text { analysed using } \\
\text { logistic } \\
\text { regression } \\
\text { modelling with } \\
\text { data collected on } \\
\text { exposure } \\
\text { variables in wave } \\
1 \text { as predictors. }\end{array}$ & $\begin{array}{l}\text { demographics, } \\
\text { parental marital } \\
\text { status. }\end{array}$ & $\begin{array}{l}\text { positive youth } \\
\text { development } \\
\text { significantly } \\
\text { related to lower } \\
\text { risk of Internet } \\
\text { Addiction } \\
(\mathrm{OR}=0.67)\end{array}$ & $\begin{array}{l}\text { for baseline } \\
\text { Internet } \\
\text { Addiction. } \\
\text { - No adjustmen } \\
\text { made for } \\
\text { school effect. }\end{array}$ \\
\hline $\begin{array}{l}\text { Cho et al. (2013), } \\
\text { Korea [39] }\end{array}$ & $\begin{array}{l}\text { Design: } \\
\text { Parent-reported } \\
\text { questionnaire } \\
\text { survey at } \\
\text { baseline in }\end{array}$ & $\begin{array}{l}\text { Students were } \\
\text { recruited from all } \\
\text { primary schools } \\
\text { in a small city. } \\
\text { Of the } 1112 \text { boys }\end{array}$ & $\begin{array}{l}\text { Exposure } \\
\text { variable: } \\
\text { Childhood } \\
\text { psychopathology } \\
\text { assessed by the }\end{array}$ & $\begin{array}{l}\text { Data were } \\
\text { analysed using } \\
\text { simple logistic } \\
\text { regression } \\
\text { modelling to }\end{array}$ & None & $\begin{array}{l}\text { Three symptoms } \\
\text { were identified to } \\
\text { be related to } \\
\text { Internet } \\
\text { Addiction at }\end{array}$ & $\begin{array}{l}\text { - No } \\
\text { comparison } \\
\text { between those } \\
\text { who were } \\
\text { followed and }\end{array}$ \\
\hline
\end{tabular}




\begin{tabular}{|c|c|c|c|c|c|c|c|}
\hline & $\begin{array}{l}1998 / 99 \text { and } \\
\text { respondent self- } \\
\text { reported } \\
\text { questionnaire } \\
\text { survey in } 2006 . \\
\text { Follow-up } \\
\text { duration: } \\
7 \text { years in } \\
\text { between two data } \\
\text { collection. }\end{array}$ & $\begin{array}{l}\text { in the original } \\
\text { cohort, } 524 \\
\text { obtained } \\
\text { matched data } \\
\text { between baseline } \\
\text { and follow-up. } \\
\text { The study } \\
\text { utilised the } \\
\text { subset of data } \\
\text { with complete } \\
\text { information. } \\
\text { (N=489) }\end{array}$ & $\begin{array}{l}\text { Child } \\
\text { Behavioural } \\
\text { Checklist } \\
\text { (CBCL). } \\
\text { Outcome } \\
\text { variable: } \\
\text { Internet } \\
\text { Addiction } \\
\text { measured by the } \\
\text { Korean version } \\
\text { of the Internet } \\
\text { Addiction Scale. }\end{array}$ & $\begin{array}{l}\text { ascertain the } \\
\text { association } \\
\text { between each } \\
\text { psychological } \\
\text { symptom and } \\
\text { Internet } \\
\text { Addiction }\end{array}$ & & $\begin{array}{l}\text { follow-up. } \\
\text { Withdrawal } \\
\text { (OR=1.16), } \\
\text { Anxious/Depress } \\
\text { ed (OR=1.07), } \\
\text { Thought } \\
\text { problems (1.19). } \\
\text { The total } \\
\text { Internalising } \\
(1.04) \text {, } \\
\text { Externalising } \\
(\mathrm{OR}=1.03) \text { and } \\
\text { the total score } \\
(\mathrm{OR}=1.01) \text {. }\end{array}$ & $\begin{array}{l}\text { those who } \\
\text { were lost-to- } \\
\text { follow thus } \\
\text { constituted a } \\
\text { potential } \\
\text { sampling bias. } \\
\text { - No adjustment } \\
\text { to any } \\
\text { potential } \\
\text { confounding } \\
\text { factors might } \\
\text { cause possible } \\
\text { confounding } \\
\text { bias. }\end{array}$ \\
\hline $\begin{array}{l}\text { Ko et al. (2014), } \\
\text { Taiwan [41] }\end{array}$ & $\begin{array}{l}\text { Design: } \\
\text { Self-reported } \\
\text { questionnaire } \\
\text { surveys at } \\
\text { baseline and at } \\
\text { follow-up. } \\
\text { Follow-up } \\
\text { duration: } \\
12 \text { months. }\end{array}$ & $\begin{array}{l}\text { Seventh grade } \\
\text { students } \\
\text { randomly } \\
\text { selected from } 10 \\
\text { junior high } \\
\text { schools with } 4 \\
\text { urban, } 4 \\
\text { suburban, and } 2 \\
\text { rural schools in } \\
\text { southern Taiwan } \\
\text { in } 2005 \text {. Only } \\
\text { those who were } \\
\text { assessed without } \\
\text { Internet } \\
\text { Addiction at } \\
\text { baseline were } \\
\text { included in the } \\
\text { analysis } \\
\text { (N=1630) }\end{array}$ & $\begin{array}{l}\text { Exposure } \\
\text { variable: } \\
\text { Family factors } \\
\text { assessed by the } \\
\text { Family APGAR } \\
\text { Index for family } \\
\text { function } \\
\text { Outcome } \\
\text { variable: } \\
\text { Internet } \\
\text { Addiction } \\
\text { measured by the } \\
\text { Chen Internet } \\
\text { Addiction Scale. }\end{array}$ & $\begin{array}{l}\text { Data were } \\
\text { analysed using } \\
\text { logistic } \\
\text { regression } \\
\text { modelling with } \\
\text { data collected on } \\
\text { exposure } \\
\text { variables at } \\
\text { baseline as } \\
\text { predictors. }\end{array}$ & Age and gender & $\begin{array}{l}\text { Internet parental } \\
\text { conflict was } \\
\text { significantly } \\
\text { related to } \\
\text { Internet } \\
\text { Addiction at } \\
\text { follow-up (OR= } \\
2.31 \text {, } \\
\text { 95\%C.I.=1.28- } \\
\text { 4.18). Not living } \\
\text { with mother was } \\
\text { also significantly } \\
\text { associated with } \\
\text { Internet } \\
\text { Addiction 1 year } \\
\text { later (OR=1.66, } \\
\text { 95\%C.I.=1.03- } \\
\text { 2.69) }\end{array}$ & $\begin{array}{l}\text { - The same } \\
\text { study cohort as } \\
\text { that report } \\
\text { previously by } \\
\text { Ko et al. } 2009 \\
\text { [Ref]. } \\
\text { - The } \\
\text { relationship } \\
\text { between } \\
\text { exposure and } \\
\text { outcome } \\
\text { variables was } \\
\text { examined in a } \\
\text { cohort without } \\
\text { Internet } \\
\text { Addiction at } \\
\text { baseline. } \\
\text { - No adjustment } \\
\text { made for } \\
\text { school effect. }\end{array}$ \\
\hline
\end{tabular}


Table 2. Information extracted from individual longitudinal or prospective cohort studies on the effects of Internet Addiction on health in adolescents

\begin{tabular}{|c|c|c|c|c|c|c|c|}
\hline $\begin{array}{c}\text { Reference } \\
\text { (Author, year, } \\
\text { place) }\end{array}$ & $\begin{array}{c}\text { Study design \& } \\
\text { methods }\end{array}$ & Participants & $\begin{array}{l}\text { Exposure \& } \\
\text { Outcome } \\
\text { Variable }\end{array}$ & $\begin{array}{l}\text { Method of } \\
\text { analysis }\end{array}$ & $\begin{array}{l}\text { Variables } \\
\text { Adjusted }\end{array}$ & Results & Comments \\
\hline $\begin{array}{l}\text { Lam \& Peng } \\
\text { (2010), China } \\
{[30]}\end{array}$ & $\begin{array}{l}\text { Design: } \\
\text { Self-reported } \\
\text { questionnaire } \\
\text { surveys at } \\
\text { baseline and at } \\
\text { follow-up } \\
\text { Follow-up } \\
\text { duration: } \\
9 \text { months. }\end{array}$ & $\begin{array}{l}\text { A sample of high } \\
\text { school students } \\
\text { was recruited by } \\
\text { a random } \\
\text { selection form } \\
\text { the city school } \\
\text { registry. Only } \\
\text { those who were } \\
\text { assessed without } \\
\text { mental health } \\
\text { problems } \\
\text { including } \\
\text { depression and } \\
\text { anxiety at } \\
\text { baseline were } \\
\text { included in the } \\
\text { analysis. } \\
\text { (N=1041) }\end{array}$ & $\begin{array}{l}\text { Exposure } \\
\text { variable: } \\
\text { Pathological use } \\
\text { of the Internet } \\
\text { assessed by the } \\
\text { Young's Internet } \\
\text { Addiction Scale } \\
\text { (IAT) } \\
\text { Outcome } \\
\text { variables: } \\
\text { - Depression } \\
\text { assessed by } \\
\text { the Zung Self- } \\
\text { rating } \\
\text { Depression } \\
\text { Scale } \\
\text { - Anxiety } \\
\text { measured by } \\
\text { the Zung Self- } \\
\text { rating Anxiety } \\
\text { Scale }\end{array}$ & $\begin{array}{l}\text { Data were } \\
\text { analysed using } \\
\text { Poisson } \\
\text { regression model } \\
\text { with binary } \\
\text { outcome. }\end{array}$ & $\begin{array}{l}\text { Age, sex, urban } \\
\text { or rural school, } \\
\text { family location, } \\
\text { serious illness, } \\
\text { involvement in } \\
\text { physical } \\
\text { activities, family } \\
\text { dissatisfaction, } \\
\text { and study } \\
\text { burden. }\end{array}$ & $\begin{array}{l}\text { PIU was } \\
\text { significantly } \\
\text { associated with } \\
\text { depression at } \\
\text { follow-up } \\
\text { (IRR=2.5, } \\
\text { 95\%C.I.=1.3- } \\
\text { 4.3), but not } \\
\text { anxiety. }\end{array}$ & $\begin{array}{l}\text { - Exposure and } \\
\text { outcome } \\
\text { assessments } \\
\text { relied upon } \\
\text { self-reported } \\
\text { information, } \\
\text { subjected to } \\
\text { report biases. } \\
\text { - Drop-out } \\
\text { analysis } \\
\text { conducted } \\
\text { suggesting no } \\
\text { difference } \\
\text { between drop- } \\
\text { outs and } \\
\text { retainers. }\end{array}$ \\
\hline
\end{tabular}

